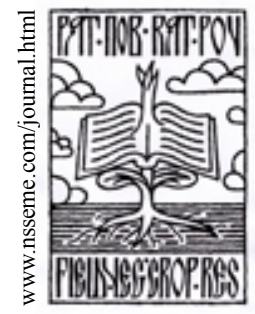

\title{
Production and Requirements for Pre-basic Seed Potato Material in the Republic of Serbia and the Republic of Srpska
}

\author{
Drago Milošević • Slobodan Milenković • Zoran Broćić • Jasna Savić • Zoran Jovović
}

\author{
received: 23 November 2011. accepted: 13 January 2012. \\ (c) 2012 IFVC \\ doi:10.5937/ratpov49-1215
}

Summary: Pre-basic seed potato material is used for basic seed (elite) and certified seed potato production. At this moment all basic seed material is imported into Republic of Serbia and Republic of Srpska, despite the fact that the method of in vitro tissue culture production of virus-free seed potato has been developed in both countries and there is a continuous demand for pre-basic and basic seed potato. Current total production is significantly lower than actual requirements. In the $80 \mathrm{~s}$ and $90 \mathrm{~s}$ of the previous century two modern facilities for production of virus-free seed potato and certified seed were built in Sokolac (Republic of Srpska) and Guča (Republic of Serbia). Although facilities were well-equipped, seed potato production was permanently ceased in 2000. The presence of high infection pressure dominated by potato virus $\mathrm{Y}$ is shown in the Republic of Serbia and the Republic of Srpska. This paper gives an overview of pre-basic seed potato material production in both countries over the last two decades.

Key words: seed potatoes, potatoes, pre-basic material, production

\section{Introduction}

Pre-basic seed potato is the source material for basic and certified seed potato production (Fig. 1) and there is a continuous demand for it at the regional market. Potato production for different purposes is based on high quality seed material which might be infected by viruses and other pathogens according to tolerance level (Van der Zaag 1987, Grousset \& Smith 1998, OEPP/ EPPO 2004). Health conditions, especially infections caused by viruses limit the production of high quality seed potato in all ex-Yugoslavian countries (Milošević \& Petrović 2000, Milošević \& Đalović 2004, 2005, Milošević 2006, 2007, Broćić et al. 2009). Seed potato material should be renewed after two years to obtain high yield and profit in potato production.

D. Milošević

University of Kragujevac, Faculty of Agronomy in Čačak, Cara Dušana 34,32000 Čačak, Serbia

S. Milenković

Megatrend University, Faculty of Biofarming, Maršala Tita 39, 24300 Bačka Topola, Serbia

Z. Broćić* • J. Savić

University of Belgrade, Faculty of Agriculture, Nemanjina 6, 11080

Belgrade - Zemun, Serbia

e-mail: brocic@agrif.bg.ac.rs

Zoran Jovović

University of Montenegro, Biotechnical Faculty Mihaila Lalića 1, 81000 Podgorica, Montenegro
In Serbia, potato production is not profitable at the general level. The reason for this is not low prices of potato on the market, but rather low yields. High quality seed potato plays a very important role in obtaining high and stable yields, as well as other growing conditions (soil fertility and soil preparation, nutrients and water supply, disease and pest management, weed control) (Van der Zaag 1987, De Bokx \& Van der Want 1987, Milošević \& Stoiljković 1991, Milošević 2000, Ćota et al. 2007, Milošević 2007, Milošević et al. 2008, Broćić et al. 2009).

In the 80 s and 90 s of the previous century two modern facilities were built in Sokolac (Republic of Srpska) and Guča (Republic of Serbia) with the aim to establish production of virus-free and certified seed potato. At this moment there is no pre-basic seed potato material production in Serbia or in the neighbouring countries. Development of potato seed production at the national level would have a great impact in rural development of mountain regions, migration of the population would be reduced and the use of healthy seed potato material would increase average potato yields and profits of potato producers (Milošević \& Bugarčić 2005, Milošević

Acknowledgement: This research was funded by the Ministry of Education and Science of Republic of Serbia, through implementation of Project TR31043 "Studies on plant pathogens, arthropods, weeds and pesticides with a view to developing the methods of biorational plant protection and safe food production". 
et al. 2008). Thus, seed potato production should be renewed both in the Republic of Serbia and the Republic of Srpska with the aim of satisfying the continuous demand for pre-basic and basic seed potato (Milošević \& Bugarčić 2005, Broćić et al. 2009).

This paper gives an overview of pre-basic seed potato material production in the Republic of Serbia and the Republic of Srpska over the past two decades. results of studies on the degree of degeneration during potato crop growth in Serbia, the degree of degeneration is extremely high (Milošević 1992a, 1992b, 1996). Around 50-90\% of healthy potato is infected in areas with potato production every year. In Serbia and the Republic of Srpska, the need for seed potato is much higher than current amounts used for potato production. Around 10,000-12,000 t of seed potato are imported into both countries annually (Milošević \& Đalović

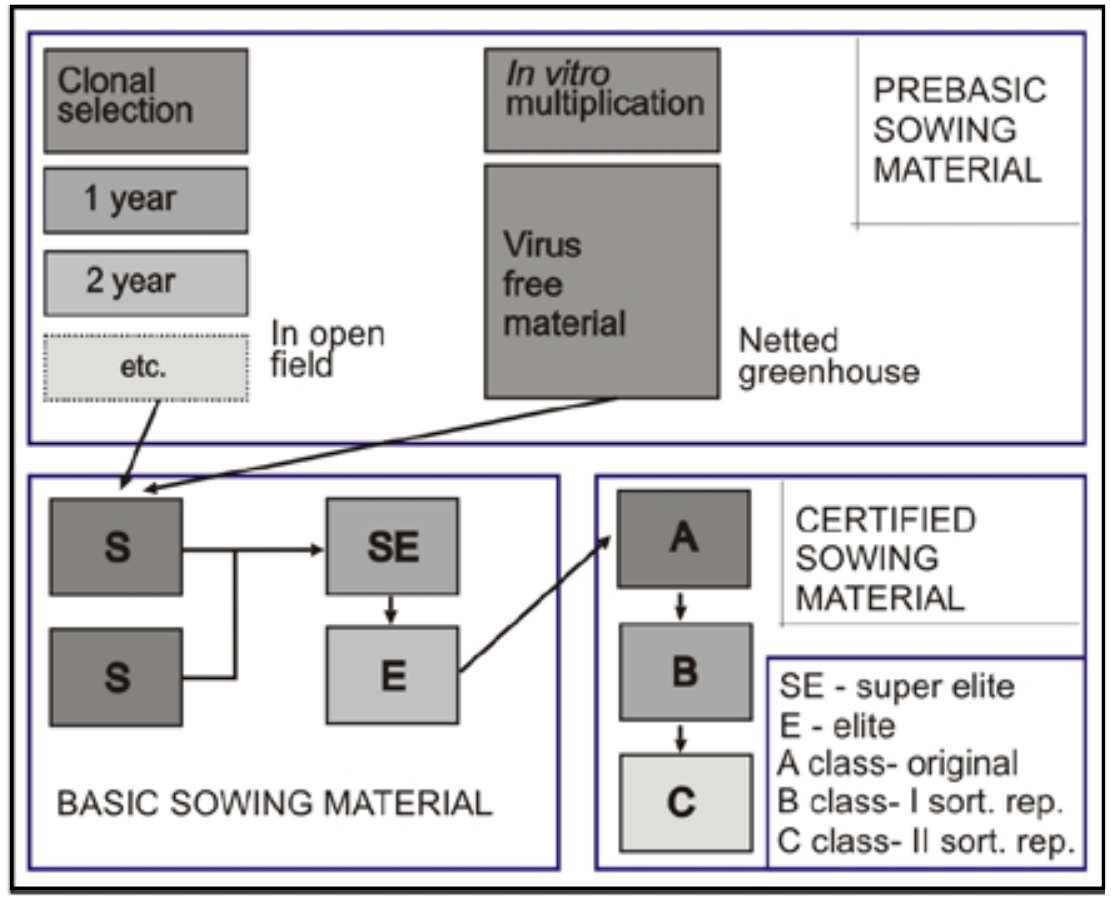

Figure 1. Potato seed production procedure according to NAK, Holland (modified by Milošević 2009) Slika1. Šematski prikaz procedure proizvodnje semenskog krompira prema NAK-u, Holandija (mod. Milošević 2009)

\section{Demand for Seed Potato in the Republic of Serbia and the Republic of Srpska}

In the Republic of Serbia and the Republic of Srpska seed potato is needed for table and processing potato production. Estimation of seed potato demands is based on total area sown and is also affected by other factors such as degree of seed potato degeneration and the use of seed potato by farmers.

The degree of seed potato degeneration should seriously be taken into consideration. Immediately after their introduction into Europe, potato crops started to suffer degeneration or "run off" due to continuous vegetative reproduction that caused physiological changes in the cultivars (Salaman 1970). Based on current potato production and
2004). As planting material should be renewed after three years, estimated annual needs are higher than 50,000 t. Certified seed potato is used on less than $10 \%$ of the total potato production area, and using such small amounts of certified seeds cannot provide high yields and profits. In summary, the idea for building facilities for prebasic, basic and certified seed potato in Guča and Sokolac was justified.

\section{Potato Breeding and Production of Pre-basic Planting Material}

Breeding new potato genotypes (varieties) is strongly connected to a developed production of pre-basic planting material. Over the years potato breeding in Serbia was financially supported 
by the government through scientific projects, although not even pre-basic planting material had been produced. Around the world, potato breeding is performed by seed companies which produce planting material and promote growing of their own varieties.

Production of pre-basic and basic planting material would be of great importance for the Republic of Serbia and the Republic of Srpska despite the fact that germplasm of local varieties has been lost due to the negligence of breeders, e.g. varieties Jelica and Dragačevka are stored in the Czech Republic. Foreign so-called "free" varieties could be used without paying for a license due to expiring of the obligation to pay the fees for multiplication, as well as newer varieties. The import of elite stocks could be decreased by free multiplication of varieties such as Desiree, Kennebec, Jaerla and others widely grown in both countries. However, changing the varieties and introduction of newer ones will not be enough to improve potato production in our region.

\section{Facilities for Virus-Free Seed Potato Production}

Facilities for virus-free potato planting material were built in Sokolac (Republic of Srpska) during the 1980s. A laboratory for virus-free potato planting material started to work in Guča (Republic of Serbia) with full capacity in 1996. Sokolac is located at a high altitude above sea level, and thus has better conditions due to a decreased population of aphids and sources of potato virus $Y$ infection. In Guča, production steadily increased until 2000, with two cycles per year. For the first time, a certain amount of virusfree planting material was produced in the field in 2000 , but production ceased soon afterwards.

Ten years after seed potato production ceased in Serbia, many questions could be raised. A crucial problem could be that virus-free plantlets had been produced by tissue culture without thinking forward about multiplying virus-free tubers up to certain quantities that would economically be justified. It should also be taken into consideration that multiplication of virus free material is possible only in fields free of sources of infection at both geographical sites (Milošević 2009).

The main cause for closing the facilities was lack of knowledge in epidemiology of viruses and methods of control. After the facilities were built, the majority accepted results obtained after many years of research showing that extremely high virus infection pressure is present in the Guča region (Milošević 1995, Milošević \& Đalović 2002,
Milošević \& Đalović 2004). Under conditions of very high infection of potato virus $\mathrm{Y}$ in the fields, virus free planting material would be infected quickly, as showed by Milošević (1992). Potato virus $Y$ spreads dominantly, calculated to be 10 20:1 in comparison with potato leafroll virus (PLRV).

\section{Methods of Potato Pre-basic and Basic Planting material Production}

The process of seed potato production could simply be defined as multiplication of tubers from selected healthy plants for a few generations, under adequate protection from diseases until sufficient amounts are obtained of healthy tubers - pathogen free or infected under tolerance as regulated by the law. There are two methods of potato pre-basic and basic planting material production: clone breeding and in vitro production of virus-free plants by tissue culture. Both methods have certain advantages and disadvantages (Milošević 1998a, 2009).

Using classic clone breeding, selected healthy plants are multiplied by cloning for a few years (Fig. 2) (Milošević 2009a). At production sites with low pressure of viruses and under adequate protection from viruses and other plant diseases, it is possible to obtain high quality pre-basic and basic planting material by this method. As viruses are widely spread in our region, there is a high risk of infection by viruses during the period of multiplication in the field, as indicated by Milošević $(1989,1995)$. This method is applicable under current conditions but also brings a high risk of infection by viruses.

Epidemics and the high speed of potato infection by potato virus Y (PVY) limit the production of pre-basic, basic and certified planting material in South-East Europe and other regions (Weidemann 1988, Buturović \& Kus 1989, Chrzanowska 1991, Horvath et al. 1995, Milošević 1992a, 1992b, 1995, 2009b, Horvath \& Wolf 1999, Milošević \& Petrović 2000, Jasnić et al. 2003). Production of virus-free potato plants by tissue culture in vitro has advantages due to protection against vectors of potato viruses in the laboratory, culture room and greenhouse (Fig. 3) (Ružić et al. 1996, Todorović et al. 1997, Milošević et al. 1997, Milošević \& Bratić 2000). Basic knowledge in epidemiology of viruses is also necessary for the application of this method otherwise good results cannot be expected.

Therefore, under conditions of high infection pressure nosuccess is guaranteed without thorough knowledge in epidemiology, transmission 
and control of viruses. At the same time, both methods are suitable for the Republic of Serbia and the Republic of Srpska due to the existence of sites in mountain regions with reduced aphid populations and sources of infection (Milošević 1996, 1998b).
Introduction of Tissue Culture Method in Potato Pre-basic and Basic Planting material Production

Application of in vitro tissue culture (micropropagation) has become routine in the production of virus-free plants. Also, there is no

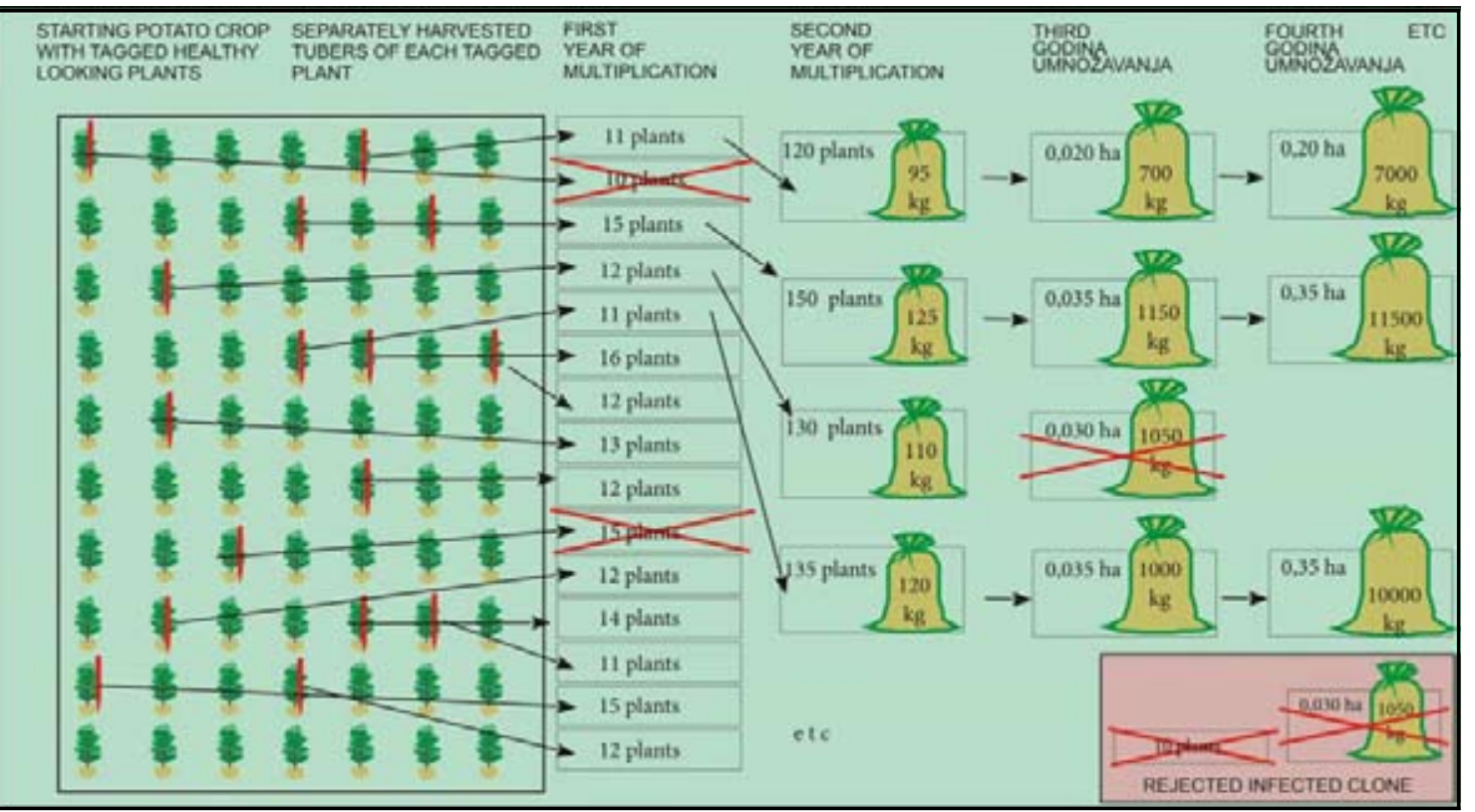

Fig. 2. Seed potato production using clone breeding (Milošević 2009a)

Slika 2. Šematski prikaz proizvodnje semenskog krompira klonskim odabiranjem (Milošević 2009a)

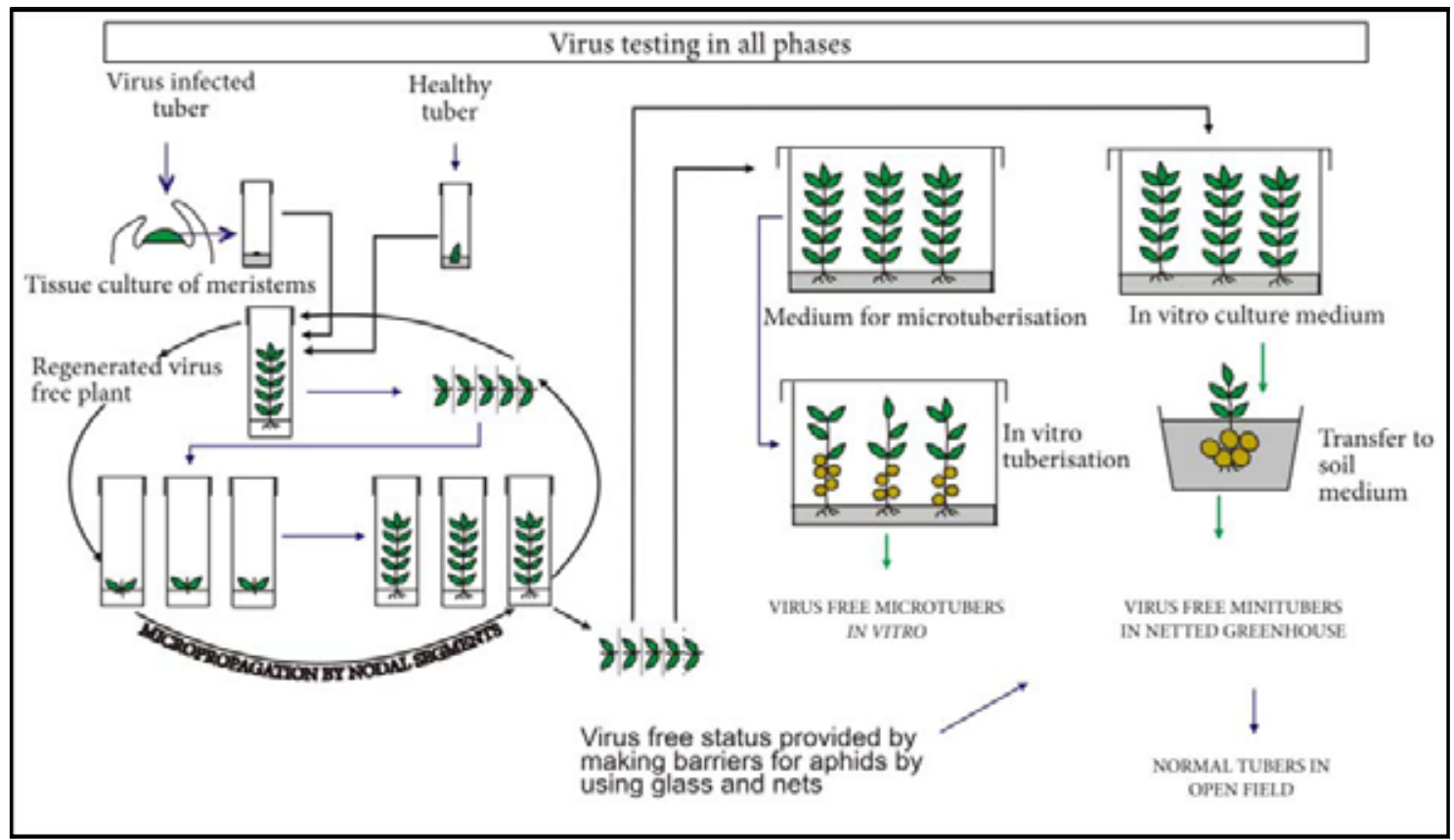

Fig. 3. Virus-free seed potato production using in vitro tissue culture (Milošević 2008a)

Slika 3. Šematski prikaz proizvodnje bezvirusnog semenskog krompira kulturom tkiva in vitro (Milošević 2008a) 
problem to apply meristem culture in maintaining the genetic integrity of genotypes (Espinoza et al. 1984, Ružić et al. 1996, Milošević et al. 1997, Milošević \& Bratić 2000). At this stage the only factor that could limit production is the capacity of the culture room. Problems occur when virus-free plant material (plantlets or tubers) is transferred to a netted greenhouse and particularly to the field (Milošević et al. 2007, Milošević 2009). This is the moment when there might be a risk of winged aphids being present in the space used for growing virus-free plants. This is the reason why the process of multiplication of virus-free and pre-basic seed potato has never been properly established, not even the production of commercial classes of seed potato.

The method of clone breeding in Serbia and Srpska has never been established properly nor applied in pre-basic planting material production due to the lack of a serious approach to knowledge in the control and epidemiology of viruses. Authorities who were making decisions at the national level thought that introduction of micropropagation using tissue culture in vitro could save the problem. Switching to this new method happened despite the lack of basic knowledge in seed potato production.

\section{Conclusions}

In the Republic of Serbia and the Republic of Srpska average potato yields are very low, making edible potato production non-profitable. There is a continuous demand for potato planting material as all quantities of imported seed potato (elite and class A) degenerate quickly if not multiplied under organized production with permanent and strict control. Based on the total area sown, at least 50,000 $t$ of seed potato is needed annually. Due to the negligence of breeding institutions, local varieties have either been lost or are kept in gene banks in European countries, but pre-basic planting material could be renewed by using a small number of local and license-free foreign varieties. Pre-basic and basic planting material production is possible under conditions of high infection pressure only if adequate practice and control are applied. In our region, under current plant virus epidemiological conditions it is possible to produce pre-basic planting material using in vitro tissue culture. fkjsffksf

\section{References}

Broćić Z, Milošević D, Maklenović V, Dugalić G, Oljača J (2009): Uticaj semenarstva na proizvodnju krompira u Srbiji. Zbornik izvoda, IV Simpozijum „Inovacije u ratarskoj i povrtarskoj proizvodnji“, Beograd, Srbija, 38-39

Buturović D, Kus M (1989): The occurence of potato tuber ring necrotic disease in Yugoslavia. Book of abstracts of Virology Section Meeting EAPR. Budrio-Bologna, Italy, 6

Chrzanowska M (1991): New isolates of the necrotic strain of potato virus $\mathrm{Y}\left(\mathrm{PVY}^{\mathrm{N}}\right)$ found recently in Poland. Potato Res. 34: 179-182

Grousset F, Smith IM (1998): EPPO certification scheme for seed potatoes. Bulletin OEPP/EPPO Bulletin 28: 561-567

Ćota J, Milošević D, Đalović I (2007): Stanje i perspektive razvoja proizvodnje krompira u Bosni i Hercegovini. U: D Knežević (ured.), Unapređenje poljoprivredne proizvodnje na Kosovu i Metohiji. Poljoprivredni fakultet Priština, Lešak, 292-301.

De Bokx JA, Van der Want JPH (1987): Viruses of potatoes and seed potato production. Pudoc, Wageningen

Espinoza N, Estrada R, Tover P, Bryan J, Dodds JH (1984): Tissue Culture Micropropagation, Conservation and Export of Potato Germplasm. International potato Center (CIP), Lima, $1-21$

Horvath S, Wolf I (1999): Virological problems of potato production in Hungary. Book of abstracts of $14^{\text {th }}$ Triennial Conference of the EAPR. Sorrento, Italy, 383-384

Horvath S, Wolf I, Basky Z, Kohhary E (1995): Epidemical infection of potato virus Y potyvirus (PVY) in 1993-1994 in Hungary. Proceeding of the 9th EAPR Virology Section Meeting. Bled, Slovenia, 99-101

Jasnić S, Milošević D, Bagi F (2003): Virusi paraziti semena. Biljni lekar 6: 610-621

Milošević D (1989): Rasprostranjenost nekih virusa krompira u području Zapadne Srbije. Zaštita bilja 40: 367-374

Milošević D, Stoiljković B (1991): Uticaj višegodišnjeg umnožavanja krtola u uslovima visokog infekcijskog pritiska na stepen izrođavanja krompira. Savremena poljoprivreda 5: 19-24

Milošević D (1992a): The occurence of the necrotic strain of potato virus $\mathrm{Y}\left(\mathrm{PVY}{ }^{\mathrm{N}}\right)$ in some localities in Serbia. Zaštita bilja 43: $197-202$

Milošević D (1992b): Nekrotični soj Y virusa (PVYN) i njegov značaj u proizvodnji sjemenskog krompira. Zbornik radova Jugoslovenskog savetovanje o krompiru, Guča, Srbija, 87-90

Milošević D (1995): Rasprostranjenost i štetnost virusa krompira u Jugoslaviji. Biljni lekar 6: 633-637

Milošević D (1996): Uticaj lokaliteta i načina prenošenja na intenzitet širenja nekih virusa krompira. Zaštita bilja 47: 205218

Milošević D, Milinković M, Bošković T (1997): Proizvodnja bezvirusnog semenskog krompira kulturom tkiva u Jugoslaviji. Selekcija i semenarstvo 3-4: 121-124

Milošević, D (1998a): Bolesti krompira sa osnovama semenarstva. Institut „Srbija“ i Draganić, Beograd

Milošević D (1998b): Značaj brdsko-planinskih područja Jugoslavije u proizvodnji sjemenskog krompira. International conference TEMPO-HP '98. Čačak, Srbija. Savremena poljoprivreda Vanr. broj 65-71

Milošević D (2000): Stanje i perspektive proizvodnje semenskog krompira u Jugoslaviji. Arhiv za poljoprivredne nauke 61: 5-27

Milošević D, Bratić M (2000): Proizvodnja bezvirusnog i osnovnog semenskog krompira u Jugoslaviji - stanje i mogućnosti. Arhiv za poljoprivredne nauke 61: 115-130

Milošević D, Petrović D (2000): Virusne bolesti i proizvodnja semenskog krompira. Zbornik rezimea Naučno-stručnog savjetovanja agronoma Republike Srpske sa međunarodnim učešćem, Teslić, Bosna i Hercegovina, 59-60 
Milošević D, Đalović I (2004): Y virus krompira-ograničavajući činilac semenarstva krompira u Srbiji. Savetovanje o biotehnologiji, Agronomski fakultet-Čačak, Zbornik radova 9: 53-66

Milošević D, Đalović I (2005): Zdravstveno stanje-limitirajući činilac proizvodnje kvalitetnog sjemenskog krompira u državama nastalim raspadom Jugoslavije. Zbornik rezimea II Simpozijuma o zaštiti bilja u Bosni i Hercegovini. Teslić, Bosna i Hercegovina, 16-17

Milošević D, Bugarčić Ž (2005): Uticaj nekih činilaca na zdravstveno stanje sadnog materijala i ukupnu proizvodnju krompira u Srbiji. Traktori i pogonske mašine 10: 138-148

Milošević D (2006): Proizvodnja i kontrola zdravstveno ispravnog sadnog materijala kao važnog činioca rentabilne proizvodnje krompira. Zbornik radova XI Savetovanja o biotehnologiji. Čačak, Srbija, 11: 365-373

Milošević D, Bugarčić Ž, Ivanović M, Ivanović M (2007): Upravljanje zdravstvenim stanjem semenskog krompira. Zbornik rezimea XIII Simpozijuma sa savetovanjem o zaštiti bilja. Zlatibor, Srbija, 26-28

Milošević D (2007): Bezvirusni sadni materijal - osnova za intenzivnu proizvodnju krompira i povećanje resursa hrane. Unapređenje poljoprivredne proizvodnje na Kosovu i Metohiji. Poljoprivredni fakultet Priština - Lešak, 282-291

Milošević D, Đalović I, BugarčićŽ (2008): Značaj zdravog sadnog materijala u cilju povećanja proizvodnje krompira. Agroznanje $1: 5-17$
Milošević D (2008): Fitopatologija - praktikum. Agronomski fakultet, Čačak

Milošević D. (2009a): Zaštita krompira - bolesti, štetočine, korovi, semenarstvo. Agronomski fakultet, Čačak

Milošević D (2009b): Virusi kao limitirajući činioci proizvodnje semenskog krompira u državama regiona - stanje i mogućnost suzbijanja. Zbornik rezimea 6. Simpozijuma o zaštiti bilja u $\mathrm{BiH}$, Tuzla, Bosna i Hercegovina, 34-35

OEPP/EPPO (2004) Normes OEPP/EPPO Standards Commodity-specific phytosanitary measures Mesures phytosanitaires par marchandise - Potato. Bulletin OEPP/EPPO Bulletin. 34: 463-477

Ružić Đ, Milinković M, Milošević D (1996): In vitro propagation of potato (Solanum tuberosum L.). Acta Horticulturae 462: 959-964

Salaman R N (1970): The history and social influence of the potato. 2nd ed. Cambridge University Press, London, U.K.

Todorović D, Đalović M, Vinterhalter B, Vinterhalter D, Milinković M, Milošević D (1997): Kultura izdanka - in vitro gen banka krompira. Zbornik rezimea XII Simpozijuma jugoslovenskog društva za fiziologiju biljaka. Kragujevac, 49

Van der Zaag DE (1987): Yield reduction in relation to virus infection. In: De Bokx, Van der Want (eds.), Virus of potatoes and seed potato production. Pudoc, Wageningen, 146-150

Weidemann HL (1988): Importance and control of potato virus Yn (PVYN) in seed potato production. Potato Research 31: $85-94$

\section{Proizvodnja i potrebe za predosnovnim sadnim materijalom krompira u Republici Srbiji i Republici Srpskoj}

\section{Drago Milošević • Slobodan Milenković • Zoran Broćić • Jasna Savić • Zoran Jovović}

Izvod: Predosnovni sadni materijal su zdrave krtole koje služe za proizvodnju osnovnog sadnog materijala krompira (elita), a na bazi toga i certifikovanog sadnog materijala krompira. Iako u Republici Srbiji i Republici Srpskoj postoje stalne potrebe za pred-osnovnim i osnovnim semenskim krompirom, kao i dva centra za njegovu proizvodnju, osnovni sadni materijal (elita) se uvozi iz Holandije i drugih zemalja zapadne Evrope. Potrebe za pred-osnovnim odnosno osnovnim sadnim materijalom (elita) su znatno veće nego što je trenutna potrošnja. Osamdesetih i devedesetih godina prošlog veka osnovana su dva savremena centra u Sokolcu (Republika Srpska) i u Guči (Republika Srbija) sa ciljem proizvodnje pred-osnovnog semenskog krompira, odnosno elite i certifikovanog sadnog materijala. Iako su oba centra bila dobro opremljena, proizvodnja bezvirusnog krompira je trajno obustavljena. U radu je dat pregled dosadašnjih istraživanja o proizvodnji pred-osnovnog sadnog materijala krompira, uz pokušaj pronalaženja odgovora na pitanje zašto je proizvodnja u ovim zemljama ugašena.

Ključne reči: krompir, predosnovni materijal, proizvodnja, semenski krompir 